\title{
Dopamine D1 and D5 Receptors Modulate Spike Timing- Dependent Plasticity at Medial Perforant Path to Dentate Granule Cell Synapses
}

\author{
Kechun Yang and John A. Dani \\ Department of Neuroscience, Mahoney Institute for Neurosciences, Perelman School of Medicine, Philadelphia, Pennsylvania 19104
}

\begin{abstract}
Although evidence suggests that DA modulates hippocampal function, the mechanisms underlying that dopaminergic modulation are largely unknown. Using perforated-patch electrophysiological techniques to maintain the intracellular milieu, we investigated how the activation of D1-type DA receptors regulates spike timing-dependent plasticity (STDP) of the medial perforant path (mPP) synapse onto dentate granule cells. When D1-type receptors were inhibited, a relatively mild STDP protocol induced LTP only within a very narrow timing window between presynaptic stimulation and postsynaptic response. The stimulus protocol produced timing-dependent LTP (tLTP) only when the presynaptic stimulation was followed $30 \mathrm{~ms}$ later by depolarization-induced postsynaptic action potentials. That is, the time between presynaptic stimulation and postsynaptic response was $30 \mathrm{~ms}(\Delta t=+30 \mathrm{~ms})$. When D1-type receptors were activated, however, the same mild STDP protocol induced tLTP over a much broader timing window: tLTP was induced when $-30 \mathrm{~ms} \leq \Delta t \leq+30$ $\mathrm{ms}$. The result indicated that D1-type receptor activation enabled synaptic potentiation even when postsynaptic activity preceded presynaptic stimulation within this $\Delta t$ range. Results with null mice lacking the Kv4.2 potassium channel and with the potassium channel inhibitor, 4-aminopyridine, suggested that D1-type receptors enhanced tLTP induction by suppressing the transient $I_{A^{-}}$-type $\mathrm{K}^{+}$current. Results obtained with antagonists and DA receptor knock-out mice indicated that endogenous activity of both D1 and D5 receptors modulated plasticity in the mPP. The DA D5 receptors appeared particularly important in regulating plasticity of the mPP onto the dentate granule cells.
\end{abstract}

Key words: dentate gyrus; hippocampus; LTP; potassium current; STDP; synaptic plasticity

\section{Introduction}

The hippocampus is thought to be critical for several higherorder brain functions, including learning and memory. The perforant path input from the entorhinal cortex affects the function of the entire hippocampus while providing place and spatial information essential for an animal's survival (Hargreaves et al., 2005; Stepan et al., 2012; Kheirbek et al., 2013; Van Cauter et al., 2013). The dentate gyrus region of the hippocampus receives afferent information via the perforant path, initiating the primary trisynaptic circuit of the hippocampus (Hsu, 2007; Stepan et al., 2012).

Although there is presently some controversy about the source of dopaminergic innervation (Smith and Greene, 2012),

Received June 12, 2014; revised Sept. 5, 2014; accepted Oct. 4, 2014.

Author contributions: K.Y. and J.A.D. designed research; K.Y. performed research; K.Y. analyzed data; K.Y. and J.A.D. wrote the paper.

This work is supported by grants from the National Institutes of Health-National Institute on Drug Abuse (DA09411 and DA036572) and National Institute of Neurological Disorders and Stroke (NS21229). We thank Dr. Ta0 A. Zhang for help initiating the experiments, Drs. Xiaolong Jiang and Fei Cao for assistance with biocytin staining, and Peter D. Reese and Dr. Mariella De Biasi for assistance with genotyping. We thank Dr. David R. Sibley for providing D1/5 K0 mice and Dr. Jeanne M. Nerbonne for providing Kv4.2 K0 mice.

The authors declare no competing financial interests.

Correspondence should be addressed to John A. Dani, Department of Neuroscience, Mahoney Institute for Neurosciences, Perelman School of Medicine, Philadelphia, PA 19104. E-mail: johndani@upenn.edu.

DOI:10.1523/JNEUROSCI.2400-14.2014

Copyright $\odot 2014$ the authors $\quad 0270-6474 / 14 / 3415888-10 \$ 15.00 / 0$ earlier studies suggested the hippocampus receives dopaminergic projections mainly from the midbrain, including the VTA, substantia nigra, and retrorubral field (Gasbarri et al., 1994a,b, 1996). Quantitative real-time PCR confirmed that D1 and D5 DA receptors are found in the hippocampus, including in the dentate gyrus (Mu et al., 2011). Consistent with those findings, experimental procedures that are expected to activate the hippocampal-VTA loop, such as an intraperitoneal injection of cocaine or introducing a rodent to a novel environment, facilitate LTP induction in the hippocampus and can elicit spatial learning and memory (Lisman and Grace, 2005; Iñiguez et al., 2012; da Silva et al., 2012; Edelmann and Lessmann, 2013; Hansen and ManahanVaughan, 2014). Furthermore, in freely moving mice nicotine induces or enhances the in vivo induction of dentate gyrus LTP by a mechanism requiring the activation of D1-type receptors (Tang and Dani, 2009).

When D1-type receptor (or $\beta$-adrenergic receptor) activation was combined with paired presynaptic and postsynaptic stimulation, timing-dependent LTP (tLTP) could be induced in visual cortical pyramidal neurons (Seol et al., 2007), in CA1 pyramidal neurons (Lin et al., 2003; Edelmann and Lessmann, 2011, 2013), in cultured hippocampal neurons (J.C. Zhang et al., 2009), or in dentate gyrus slices (Hamilton et al., 2010). The timing relationship between presynaptic and postsynaptic stimulation and the mechanisms underlying the dopaminergic modulation of tLTP 

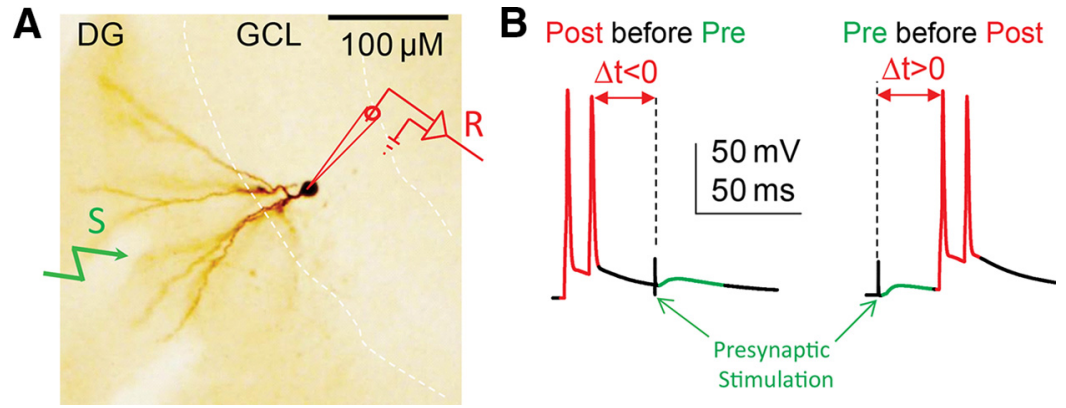

Figure 1. DG and the STDP protocols. $A$, Illustration of a typical granule cell within the granule cell layer (GCL) and the electrode placements are indicated ( $S$, stimulation electrode; $R$, recording electrode). $\boldsymbol{B}$, The STDP protocols with paired presynaptic stimulation and two postsynaptic action potentials at $100 \mathrm{~Hz}$. $\Delta t<0$ means postsynaptic before presynaptic stimulation, and $\Delta t>0$ means presynaptic before postsynaptic stimulation.
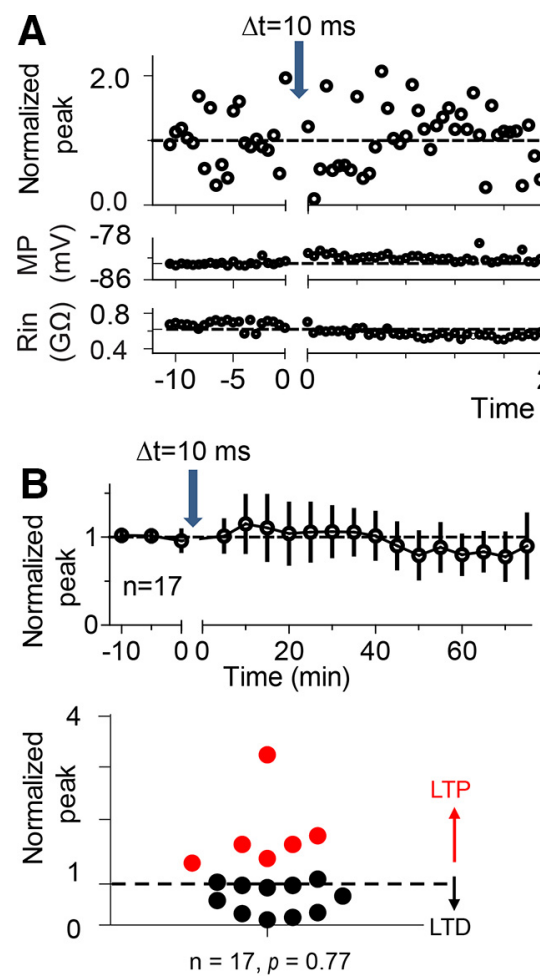

(min)
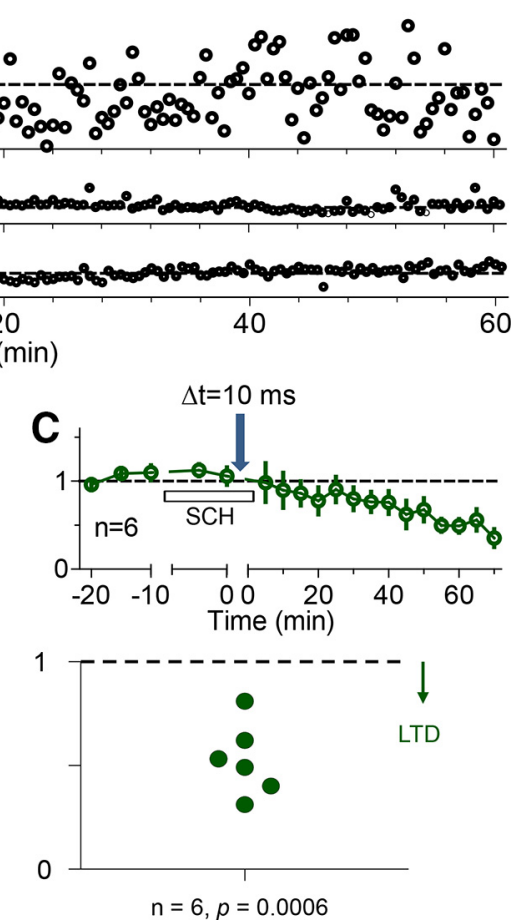

Figure 2. Consequences of the STDP protocol with $\Delta t=10 \mathrm{~ms}$. $\boldsymbol{A}$, An example time course and magnitude of the synaptic strength induced by the $\Delta t=10 \mathrm{~ms}$ protocol (top). All data points were normalized to the mean baseline value. The corresponding membrane potential (MP) (middle) and input resistance (Rin) (bottom) are plotted on the same time course. $B, C$, Summary point diagrams showing alterations in synaptic efficacy produced by the $\Delta t=10 \mathrm{~ms}$ protocol (at the downward arrow) in all granule cells recorded in the absence (black data) and presence (green data) of $20 \mu \mathrm{m} \mathrm{SCH}$ (D1-type receptor antagonist), respectively. Average of normalized peak values counted per $3 \mathrm{~min}$ or $5 \mathrm{~min}$ bin for prestimulation baseline and poststimulation period, respectively (top). Population graph illustrating the magnitude of synaptic change induced by the same $\Delta t=10 \mathrm{~ms}$ protocol (bottom).

induction in the dentate gyrus, however, are largely unknown. In addition, some of these previous studies used the whole-cell patch-clamp approach, which disrupts the intracellular milieu and potentially influences the g-protein signaling cascade initiated by the DA receptors. Therefore, to examine D1 and D5 receptor influence over tLTP, we used perforated-patch techniques to preserve the intracellular environment and applied mild, low-frequency spike timing-dependent protocols. We found that both D1 and D5 receptors participate in tLTP. Furthermore, the DA receptors act via a mechanism consistent with inactivation of a transient $\mathrm{K}^{+}$current to boost induction of tLTP.
Overall, our results indicate that an elevated DA concentration increases the probability for inducing LTP and increases the synaptic firing circumstances that will initiate LTP. Consequently, the results suggest that there is an increased probability of saving incoming information along the perforant path as synaptic plasticity when that information arrives with a coincident DA signal in the dentate gyrus. Because DA signaling is elevated in response to unpredicted salience and rewarding events (Schultz, 1997), this plasticity process would associate unpredicted salient and rewarding events with the concomitant environmental information, such as spatial information, carried on the perforant path.

\section{Materials and Methods}

Slice preparation. All of the procedures, including the preparation of mouse hippocampal slices, were approved by the Institutional Animal Care and Use Committee. Hippocampal slices were prepared as previously described (T.A. Zhang et al., 2010). Briefly, wild-type C57BL/6, Kv4.2 KO, or D1 or D5 receptor KO mice of either sex (17-30 d old) were anesthetized with a mixture of ketamine $(42.8 \mathrm{mg} / \mathrm{ml})$, xylazine $(8.6 \mathrm{mg} / \mathrm{ml})$, and acepromazine $(1.4$ $\mathrm{mg} / \mathrm{ml}$ ) before decapitation. Then the brain was removed and sectioned with a vibratome (Leica VT 1000S) in ice-cold low-calcium, high-magnesium ACSF containing the following (in mM): $125 \mathrm{NaCl}, 25 \mathrm{NaHCO}_{3}, 2.5 \mathrm{KCl}$, $1.25 \mathrm{NaH}_{2} \mathrm{PO}_{4}, 7 \mathrm{MgSO}_{4}, 0.5 \mathrm{CaCl}_{2}$, and 25 D- $(+)$-glucose saturated with $95 \% \mathrm{O}_{2}$ and $5 \%$ $\mathrm{CO}_{2}$. Horizontal slices ( $270 \mu \mathrm{m}$ thick) containing the hippocampus and the entorhinal cortex were kept in a homemade chamber containing the same solution at $32^{\circ} \mathrm{C}$ for 20-30 $\mathrm{min}$ and then maintained at room temperature $\left(22 \pm 1^{\circ} \mathrm{C}\right)$ for at least $1 \mathrm{~h}$ until recording.

Perforated patch-clamp recordings. The hippocampal slice was placed in a homemade recording chamber and submerged in continuously flowing oxygenated ACSF (1-2 $\mathrm{ml} / \mathrm{min}$ ) containing the following (in $\mathrm{mM}$ ): 125 $\mathrm{NaCl}, 25 \mathrm{NaHCO}_{3}, 2.5 \mathrm{KCl}, 1.25 \mathrm{NaH}_{2} \mathrm{PO}_{4}, 1$ $\mathrm{MgSO}_{4}, 2 \mathrm{CaCl}_{2}$, and $25 \mathrm{D}-(+)$-glucose, maintained at $32-34^{\circ} \mathrm{C}$ by an automatic temperature controller (TC-324B; Warner Instrument). To measure EPSPs, picrotoxin (100 $\mu \mathrm{m}$; SigmaAldrich) was routinely included in the ACSF. Patch recording electrodes (3-5 M $\Omega$ ) were pulled from borosilicate glass capillaries (TW150-4; WPI) using a Narishige vertical puller (PC-10) and filled with intracellular solution containing the following (in mM): 140 potassium gluconate, $5 \mathrm{KCl}, 10 \mathrm{HEPES}, 0.2 \mathrm{EGTA}, 2 \mathrm{MgCl}_{2}, 4 \mathrm{MgATP}$, $0.3 \mathrm{Na}_{2} \mathrm{GTP}$, and $10 \mathrm{Na}_{2}$-phosphocreatine, $\mathrm{pH}$ 7.3, with $\mathrm{KOH}$. Perforated patch-clamp recordings were made with the aid of amphotericin $\mathrm{B}$ (200 $\mu \mathrm{g} / \mathrm{ml}$; Sigma-Aldrich; K. Yang et al., 2009, 2011, 2013). The best perforated-patch whole-cell recordings can last much longer than conventional whole-cell recordings. Most of the perforated-patch whole-cell recordings last $>1 \mathrm{~h}$ and often last $>2 \mathrm{~h}$. Thus, perforated-patch wholecell recordings make it possible for us to obtain stable baseline recording for $10 \mathrm{~min}$, then to bath apply drugs for another 10-15 $\mathrm{min}$, and further 
to observe changes in synaptic strength for at least $40-50 \mathrm{~min}$, which are required for typical LTP studies. Furthermore, the tLTP induction threshold by the spike timing-dependent plasticity (STDP) protocols is lower when perforated, but not when conventional whole-cell recording is used. For example, when using conventional whole-cell recordings an STDP stimulus paradigm twice is strong as that used for perforated whole-cell recordings was needed to induce tLTP (data not shown).

EPSPs were evoked by a bipolar electrode (Stereotrode Tungsten; WPI) placed within the medial perforant pathway (mPP), usually $150-$ $200 \mu \mathrm{m}$ away from the granule cell being recorded (Fig. 1A). The STDP protocols contained presynaptic stimulation and two postsynaptic action potentials (two spikes at $100 \mathrm{~Hz}$ ), which were delivered 60 times at 0.33 $\mathrm{Hz}$ in $3 \mathrm{~min}$ (Fig. 1B). Spikes were evoked by $2 \mathrm{~ms}$ square pulses of current $(1-1.5 \mathrm{nA})$ injections. The time interval $(\Delta t)$ between the onset of presynaptic stimulation and postsynaptic spike of STDP protocols was defined as shown in Figure 1B. Typically, the fold change of potentiation or depression, termed as STDP ratio (J.C. Zhang et al., 2009), was defined as the mean peak amplitude of 40 consecutive EPSPs taken 30-50 min after the end of the paired induction protocols divided by the average of the initial 20 consecutive EPSPs defined as the $10 \mathrm{~min}$ baseline (Luu and Malenka, 2008). Failures were included in the measurements. For time course plots, time points of all data were converted to fold changes and averaged every 3, 5, and $10 \mathrm{~min}$. Data were collected using a 200B amplifier (Molecular Devices) and acquired via a digitizer (Digidata 1322A; Molecular Devices) at $20 \mathrm{kHz}$. Some recorded granule cells were intracellularly backfilled with biocytin $(2 \mathrm{mg} / \mathrm{ml})$ after patch-clamp recording. After backfilling, the slices were postfixed $10-14 \mathrm{~d}$ in $4 \%$ paraformaldehyde and $2.5 \%$ glutaraldehyde in $100 \mathrm{~mm}$ PBS for DAB staining (Fig. 1A).

Stimulation pulses were generated by a stimulus isolator (A365; WPI) every $30 \mathrm{~s}$. Stimulation intensity $(10-50 \mu \mathrm{A})$ varied from slice to slice, but was usually adjusted to produce EPSPs $(3-10 \mathrm{mV})$ that were $<30 \%$ of the maximum amplitude, which was the threshold stimulation to evoke action potentials. To judge the recording conditions continuously, we monitored the membrane potential (MP) and the input resistance (Rin), which was calculated by measuring the voltage changes in response to current $(200 \mathrm{~ms},-0.01 \mathrm{nA})$ injected via the recording pipette. The MP and Rin were measured during the entire recording period in all cells recorded (Fig. 2A). The recordings were terminated and data were not used if MP or Rin changed by $>30 \%$. A stable 10 min baseline of EPSPs was first obtained before the application of drugs and before the STDP induction protocols.

Chemicals and drug application. $\mathrm{R}(+)-\mathrm{SCH}-23390$ hydrochloride, ( \pm )-6-chloro-PB hydrobromide (SKF-81297), APV, and barium chloride dehydrate $\left(\mathrm{BaCl}_{2}\right)$ were purchased from Sigma-Aldrich; all other compounds were products of Tocris Bioscience. Following a $10 \mathrm{~min}$ stable baseline recording, chemicals used in this study were washed in 10-15 min before repetitive STDP protocols and washed out beginning 3-5 min after the pairing stimulation.

Statistical analysis. Values were expressed as mean \pm SEM, and the number of experiments was indicated by $n$. The peak amplitude of the EPSPs was normalized to baseline. Paired/unpaired Student's $t$ test or one-way ANOVA with Tukey post hoc comparison test was performed for the statistical analyses, and $p<0.05$ was considered to be statistically significant.

\section{Results}

Dentate granule cells can be discriminated from other cell types (T.A. Zhang et al., 2010) based on their location and their morphological characteristics (Scharfman, 1992), including the size of the cell bodies and the long apical dendrites (Fig. 1A). For this study we applied STDP protocols in which a presynaptic stimulation was either preceded by or followed by two evoked postsynaptic action potentials (Fig. $1 B$ ). In addition to morphology, granule cells were also verified by having very negative resting membrane potentials $(\mathrm{MP}=-79.5 \pm$ $0.3 \mathrm{mV}, n=346$; Fig. $2 A$ ), high input resistance ( $\mathrm{Rin}=$ $445.5 \pm 10.7 \mathrm{M} \Omega, n=437$; Fig. $2 A$ ), and practically no spon-
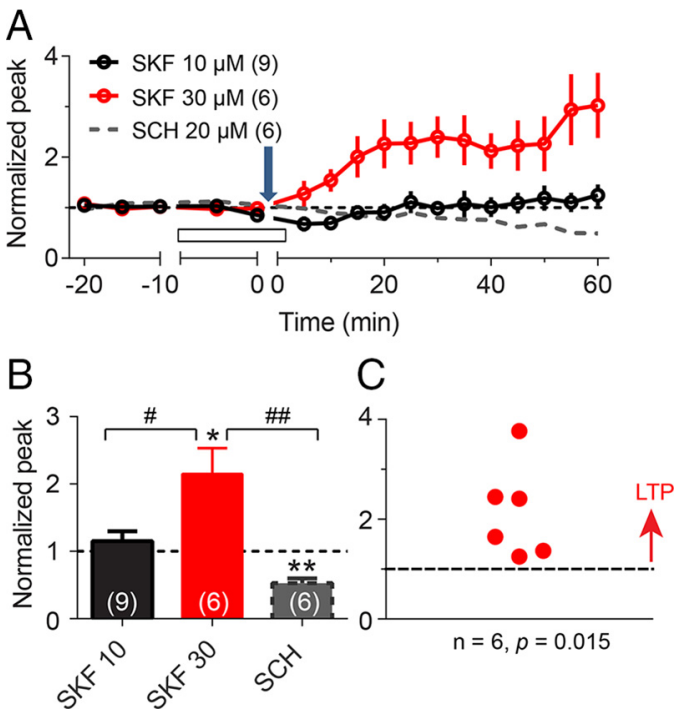

Figure 3. D1-type receptor agonist, SKF, dose dependently modulates LLTP induction by the $\Delta t=10 \mathrm{~ms}$ protocol. $A$, The tLTP induction by the $10 \mathrm{~ms}$ protocol in the presence of $10 \mu \mathrm{m}$ SKF (black), $30 \mu \mathrm{m}$ SKF (red), and $20 \mu \mathrm{m}$ SCH (dashed gray; taken from Fig. 2C), respectively. The downward arrow indicates the application of the same 10 ms STDP induction protocol, and the open bar indicates the period of bath application of the drug. $B, A$ quantified summary of the effects of SKF and SCH on synaptic strength shown as normalized peak amplitude. ${ }^{*} p<0.05,{ }^{* *} p<0.001$ compared with the baseline, and $\# p<0.05$, \#\#p<0.001 comparison between the indicated two groups. C, Summary point diagram showing alterations in synaptic efficacy produced by the $\Delta t=10 \mathrm{~ms}$ protocol in all granule cells recorded in the presence of $30 \mu \mathrm{m}$ SKF.

taneous action potential firing. However, low-frequency action potentials $(3.9 \pm 0.35 \mathrm{~Hz}, n=276)$ were evoked by injection of a $400 \mathrm{~ms}$ current (0.07 nA; Scharfman, 1992; Liu et al., 1996; Patel et al., 2004; Young et al., 2009).

\section{D1-type receptor activation influences tLTP induction}

To study DA's influence, we began by applying a $\Delta t=10 \mathrm{~ms}$ STDP protocol to the perforant path and recorded from dentate granule cells in hippocampal slices. After a stable $10 \mathrm{~min}$ baseline recording, 60 pairs of repetitive stimuli $(\Delta t=10 \mathrm{~ms})$ were applied at $0.33 \mathrm{~Hz}$ for $3 \mathrm{~min}$. In a typical experiment (Fig. $2 A$ ), the protocol induced no change in the EPSP (Normalized peak; Fig. $2 A$, top), and we required that the MP (Fig. $2 A$, middle) and the Rin (Fig. $2 A$, bottom) did not change by $>30 \%$. The average consequence of this STDP protocol was no change in the mean normalized peak amplitude of the EPSPs $(0.94 \pm 0.19, p=0.77$ vs baseline, $n=17$; Fig. $2 B$, top). However, the individual experiments $(n=17)$ showed extremely varied results, ranging from strong potentiation, tLTP, to strong depression, tLTD (Fig. $2 B$, bottom).

To investigate the influence of D1-type receptors on STDP, the D1-type receptor inhibitor, SCH-23390 (SCH; $20 \mu \mathrm{M})$, was bath applied to the slice $10 \mathrm{~min}$ before and washed out immediately after the same STDP protocol $(\Delta t=10 \mathrm{~ms})$. The average consequence of the STDP protocol was consistent tLTD, as shown in the mean normalized peak amplitude of the EPSPs ( $0.53 \pm 0.07, p=0.0006$ vs baseline, $n=6$; Fig. $2 C$, top $)$. With the D1-type receptors inhibited, all of the individual experiments $(n=6)$ showed tLTD (Fig. $2 C$, bottom). The dramatic decrease in the variability among the individual experiments can be seen by the expanded scale of the ordinate in Figure $2 C$, bottom.

Next, we examined the STDP induction by the same protocol when D1-type receptors were activated using a specific agonist, SKF-81297 (SKF). Interestingly, strong tLTP was consistently in- 

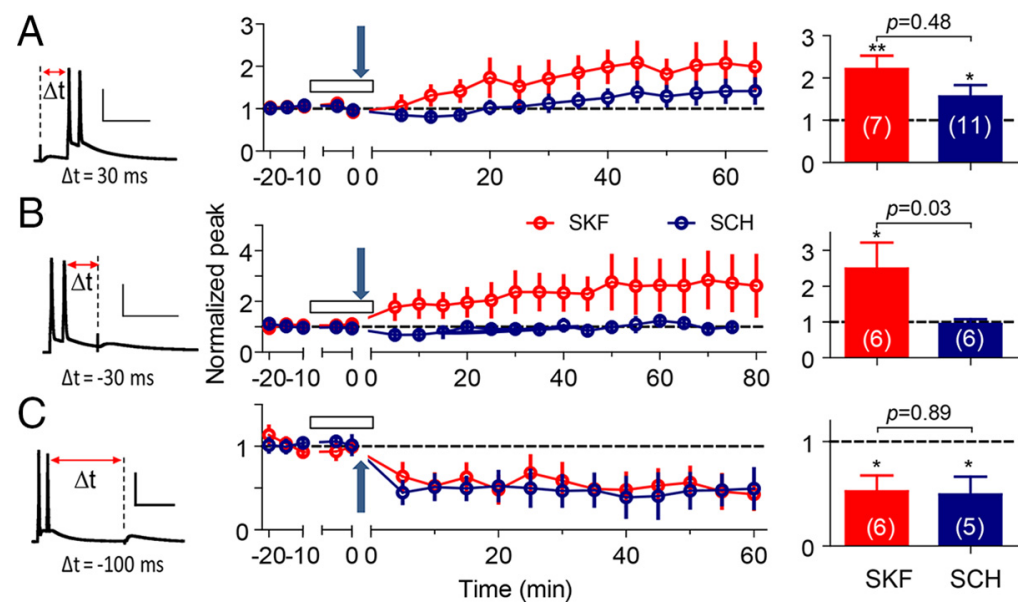

Figure 4. tLTP induction in the presence of either $30 \mu \mathrm{m} \mathrm{SKF}$ or $20 \mu \mathrm{m} \mathrm{SCH}$. The tLTP induced by the protocols with $\Delta t=30 \mathrm{~ms}$ $(\boldsymbol{A}),-30 \mathrm{~ms}(\boldsymbol{B})$, and $-100 \mathrm{~ms}(\boldsymbol{C})$. The induction protocols are illustrated in the left column. Calibration: $50 \mathrm{pA}, 50 \mathrm{~ms}$. The time course and magnitude of the alterations in synaptic strength are shown as normalized peak amplitude in the middle column. The quantified summaries of the statistical analysis are shown in right column. The arrows indicate the application of the STDP protocols, and the open bars indicate the period of drug application. ${ }^{*} p<0.05,{ }^{* *} p<0.01$ compared with the baseline; the $p$ values indicate the statistical significance between the indicated two groups.

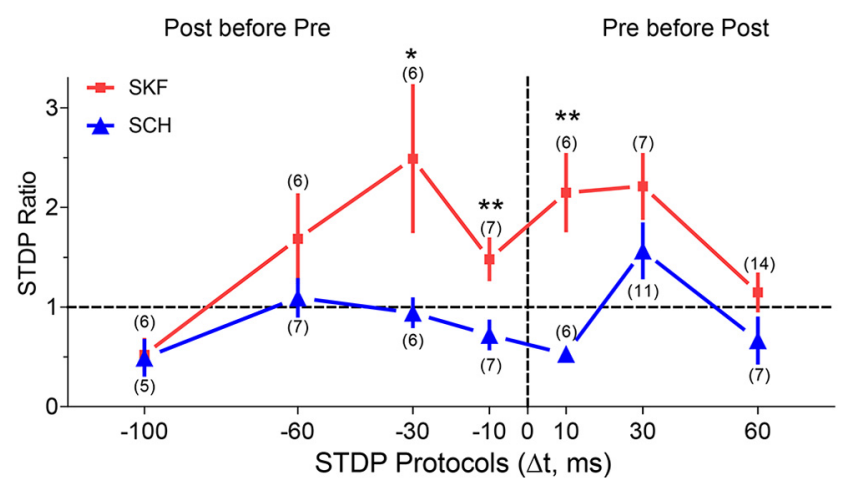

Figure 5. Summary of tLTP induction with various $\Delta t$ STDP protocols in the presence of either SKF or SCH (mean \pm SEM). ${ }^{*} p<0.05,{ }^{* *} p<0.005$ (unpaired Student's $t$ test) comparison between the indicated two groups.

duced by the $10 \mathrm{~ms}$ protocol in the presence of $30 \mu \mathrm{M}$ (but not 10 $\mu \mathrm{M}) \operatorname{SKF}(2.15 \pm 0.38, p=0.015$ vs baseline, $n=6$; Figure $3 A, B)$. With the D1-type receptors activated, all of the individual experiments $(n=6)$ showed tLTP (Fig. $3 C)$. The decrease in the STDP variability when D1-type receptors were inhibited (Fig. 2C) or were activated (Fig. 3C) suggests that D1-type receptor activity is variably activated under control conditions (Fig. $2 B$ ).

\section{Timing dependence of STDP induction}

Previous research (Bi and Poo, 1998; Watanabe et al., 2002; J.C. Zhang et al., 2009; Astori et al., 2010; Edelmann and Lessmann, 2011; Kodangattil et al., 2013) demonstrated that the direction and strength of STDP induction depended on the time between the presynaptic and postsynaptic stimulations (i.e., $\Delta t$ ). The exact synaptic change that is induced varied in different brain regions and varied under different experimental conditions (Abbott and Nelson, 2000; Dan and Poo, 2006; Shulz and Jacob, 2010). Using the perforated whole-cell patch approach to preserve intracellular signaling cascades, we examined STDP in the perforant path to granule cells. We varied $\Delta t$ from $-100 \mathrm{~ms}$ to $+60 \mathrm{~ms}$ while inhibiting $(20 \mu \mathrm{M} \mathrm{SCH})$ or activating (30 $\mu \mathrm{M}$ SKF) D1-type receptors.
Several examples illustrate the varied influence of D1-type receptors over STDP. When presynaptic stimulation preceded the postsynaptic action potentials by $\Delta t=30 \mathrm{~ms}$, the STDP protocol induced larger tLTP with D1-type activation by SKF $(2.21 \pm 0.32, p=0.004$ vs baseline, $n=7$; Fig. $4 A$, red). With D1type receptors inhibited by $\mathrm{SCH}$, there was smaller but still significant tLTP (1.56 $\pm 0.27, p=0.03$ vs baseline, $n=$ 11 ; Fig. $4 A$, blue). When the postsynaptic action potentials preceded the presynaptic stimulation with $\Delta t=-30 \mathrm{~ms}$, the STDP protocol induced tLTP with D1-type receptors activated by SKF (2.49 $\pm 0.73, p=0.04$ vs baseline, $n=6$; Fig. $4 B$, red). With D1-type receptors inhibited by $\mathrm{SCH}$, however, there was no change $(0.94 \pm 0.14, p=0.69$ vs baseline, $n=6$; Fig. $4 B$, blue). When the postsynaptic action potentials preceded the presynaptic stimulation with $\Delta t=$ $-100 \mathrm{~ms}$, the STDP protocol produced tLTD with either activation or inhibition of D1-type receptors $(0.52 \pm 0.15, p=$ 0.01 vs baseline, $n=6$ with SKF; Fig. $4 C$, red; $0.49 \pm 0.17, p=$ 0.02 vs baseline, $n=5$ with SCH; Fig. $4 C$, blue).

The summarized results for the STDP protocols with $\Delta t$ ranging from +60 to $-100 \mathrm{~ms}$ are shown in Figure 5 . With D1-type receptors inhibited (Fig. 5, SCH, blue), tLTD was more common except when presynaptic stimulation preceded the postsynaptic action potentials by $\Delta t=30 \mathrm{~ms}$. When D1type receptors were activated (Fig. 5, SKF, red), however, the timing window for tLTP induction opened broadly. The STDP protocol induced tLTP with $\Delta t$ ranging from at least +30 to $-30 \mathrm{~ms}$. The most significant change in plasticity caused by D1-type receptor activation versus inhibition came with $\Delta t$ ranging from +10 to $-10 \mathrm{~ms}$.

\section{D1 and D5 receptors participate in ILTP induction}

Both D1 and D5 receptor subtypes are expressed in the dentate gyrus (Mu et al., 2011), but pharmacologically these two DA receptor subtypes cannot be reliably distinguished. Consequently, the distinct roles of these two D1-type receptors have not been well differentiated in the dentate gyrus. For these experiments, we used DA receptor $\mathrm{KO}$ mice to characterize the roles of D1 and D5 receptors during the STDP induction protocol with $\Delta t=10 \mathrm{~ms}$. Using D1 receptor KO mice in the presence of SKF $(30 \mu \mathrm{M})$ to active DA receptors, the $10 \mathrm{~ms}$ STDP protocol induced LTD in seven of nine cells, and induced weak tLTP in the remaining two of nine cells (Fig. 6A, $B$, open squares). The averaged data showed no significant changes in synaptic strength in $\mathrm{D} 1 \mathrm{KO}$ mice $(0.79 \pm 0.11, p=0.11$ vs baseline, $n=9$; Fig. $6 A$, $B$, open squares). Using D5 receptor KO mice in the presence of SKF (30 $\mu \mathrm{M})$ to active DA receptors, the $10 \mathrm{~ms}$ STDP protocol induced only LTD in all seven granule cells examined $(0.48 \pm 0.10, p=$ 0.003 vs baseline, $n=7$; Fig. $6 A, B$, filled squares). An unpaired Student's $t$ test showed that the synaptic strength was significantly lower in D5 KO group than in D1 KO group $(p=0.04, \mathrm{D} 1$ $\mathrm{KO}$ vs D5 KO; Fig. $6 \mathrm{~B}$ ). When the $10 \mathrm{~ms}$ STDP protocol is applied in the presence of SKF, a significant difference was found among $\mathrm{WT}, \mathrm{D} 1 \mathrm{KO}$, and D5 KO groups $\left(F_{(2,19)}=16.27, p<0.001\right.$, ANOVA; Fig. 6C). When the $10 \mathrm{~ms}$ STDP protocol is applied, our 
findings indicate that both D1 and D5 receptors participate during tLTP induction at perforant path synapses in the dentate gyrus. D5 receptors appear to have a stronger impact than D1 receptors.

\section{Inactivation of potassium channels influences tLTP induction}

Evidence from studies using immunocytochemistry and in situ hybridization has shown that the Kv4.2 subunit of $I_{A}$ potassium channels is extensively expressed throughout the molecular layer of the rat dentate gyrus (Sheng et al., 1992), and it is mainly restricted to the dendrite-specific microtubule-associated protein (a dendritic marker)-positive dendrites (Sheng et al., 1992; Gu et al., 2003). Electrophysiological data confirmed that deletion of the Kv4.2 gene nearly eliminates dendritic $I_{A}$ currents, which leads to larger dendritic backpropagating action potentials and a lower threshold for LTP induction in mouse CA1 pyramidal neurons (Chen et al., 2006). It is still unclear, however, what role $I_{A}$ currents play in modulating tLTP induction in dentate granule cells. Therefore, we examined the effects of 4-aminopyridine (4-AP), an $I_{A}$ blocker, on tLTP induction. Previously, 4-AP (1-10 mM) had been used to block $I_{A}$ channels expressed in various neuronal preparations (Yu et al., 1998; F. Yang et al., 2001; Velázquez-Marrero et al., 2011; Duan et al., 2012). Based on those studies, we bath applied $1 \mathrm{~mm} 4$-AP to inhibit $I_{A}$ channels, and the $10 \mathrm{~ms}$ STDP protocol induced strong $\operatorname{tLTP}(2.02 \pm$ $0.29, p=0.013$ vs baseline, $n=5$; Fig. $7 A, B$, filled red squares).

This observation was confirmed by repeating the $10 \mathrm{~ms}$ protocol in slices from Kv4.2 KO mice. The $10 \mathrm{~ms}$ STDP protocol consistently induced tLTP $(1.74 \pm 0.22, p=0.01$ vs baseline, $n=$ 6; Fig. $7 A, B$, open red squares), even while the D1-type receptors were inhibited by SCH. The facilitating effect of 4-AP and Kv4.2 $\mathrm{KO}$ was comparable to the effect of $30 \mu \mathrm{M} \operatorname{SKF}\left(F_{(2,14)}=0.625\right.$, $p=0.6$, ANOVA; Fig. $7 B)$, indicating that inactivation of $I_{A}$ channels could serve as the underlying mechanism mediating D1-type influence over tLTP induction. An ANOVA test revealed significant increases in synaptic strength upon inhibition of $I_{A}$ with the 4-AP and the Kv4.2 $\mathrm{KO}$ groups versus the $\mathrm{SCH}$ group $\left(F_{(2.14)}=15.21, p=0.0003\right.$; Fig. $\left.7 B\right)$. Furthermore, the post hoc Tukey's test showed a significant difference between 4-AP and SCH groups $(p<0.005)$ and between $\mathrm{Kv} 4.2 \mathrm{KO}$ and SCH groups $(p<0.01)$ because the $-10 \mathrm{~ms}$ protocol also induced LTD (Fig. 5 ) in the presence of $20 \mu \mathrm{M} \mathrm{SCH}$. We further examined whether 4 -AP could also reverse the $-10 \mathrm{~ms}$ protocol-induced tLTD to tLTP. Consistent with the $I_{A}$ channels' role in the above observations from the $10 \mathrm{~ms}$ protocol, the $-10 \mathrm{~ms}$ protocol consistently induced $\operatorname{tLTP}(2.09 \pm 0.45, n=7, p<0.05$, data not shown $)$ in the presence of $1 \mathrm{~mm} 4$-AP. 4 -AP and SKF (Figs. 1, 5; $1.48 \pm 0.20$, $n=7, p<0.05)$ produced comparable effects on tLTP induction by the $-10 \mathrm{~ms}$ protocol $(p=0.2$, unpaired $t$ test, data not shown).

We next investigated the roles of inactivation of other $\mathrm{K}^{+}$ channels (i.e., not $I_{A}$ type) by bath application of two non- $I_{A} \mathrm{~K}^{+}$ channel blockers, apamin and $\mathrm{Ba}^{2+}$. Under the same experimental conditions, the $10 \mathrm{~ms}$ STDP protocol failed to induce significant potentiation of synaptic strength after either blockade of the small-conductance $\mathrm{Ca}^{2+}$-activated $\mathrm{K}^{+}$channel(SK) with $100 \mathrm{nM}$ apamin (Brenner et al., 2005) or blockade of the inward rectifier $\mathrm{K}^{+}$channel (Kir) with $100 \mu \mathrm{M} \mathrm{BaCl}_{2}$ (Benesova et al., 2012): $1.23 \pm 0.36, p=0.54$ vs baseline, $n=7$ in apamin; $1.39 \pm 0.38$, $p=0.35$ vs baseline, $n=5$ in $\mathrm{BaCl}_{2}$; Fig. $7 C, D$. An ANOVA test to examine the difference in synaptic strength among the apamin-, $\mathrm{BaCl}_{2}$, and $\mathrm{SCH}$-treated groups failed to detect a statistically significant increase in the synaptic strength arising from inhibition of the non- $I_{A}$ channels $\left(F_{(2,15)}=2.17, p=0.15\right.$; Fig. $\left.7 D\right)$. Together these findings suggest that inhibition of $I_{A}$, but not non- $I_{A}$ channels, could serve as the downstream mechanism for D1-type facilitation of tLTP induction by the $10 \mathrm{~ms}$ STDP protocol.

\section{Blockade of the MAPK pathway prevents tLTP induction}

Recent evidence suggests that the extracellular signal-regulated kinases/mitogen-activated protein kinases (ERKs/MAPKs) play an essential role in the induction of LTP in the hippocampus (Wu et al., 1999; Watanabe et al., 2002; Kelleher et al., 2004). It is also reported that blockade of the MAPK pathway results in increased activity of $I_{A}$ and suppresses tLTP induction by a $35 \mathrm{~ms}$ protocol in hippocampal CA1 pyramidal neurons (Watanabe et al., 2002). Therefore, we asked whether inhibition of the MAPK pathway with U0126 (20 $\mu \mathrm{M})$, a membrane permeable-selective MEK inhibitor (Gallagher et al., 2004), could affect tLTP induction in dentate granule cells. U0126 first was coapplied with SKF (30 $\mu \mathrm{M}$; to active DA receptors) in the recording bath solution. We found that bath application of U0126 completely prevented the induction of tLTP by the $10 \mathrm{~ms}$ STDP protocol in the presence of SKF $(0.72 \pm 0.21, p=0.11$ vs baseline, $n=6$; Fig. $8 A, C$, green circles $)$. We next asked whether inhibition of the MAPK pathway in the postsynaptic granule cell alone is sufficient to prevent the induction of tLTP. We repeated the $10 \mathrm{~ms}$ STDP protocol with U0126 $(20 \mu \mathrm{M})$ only dissolved into the internal patch-pipette solution, but not in the recording bath. To allow enough U0126 to diffuse through the perforated membrane patch, the STDP induction protocol was applied after waiting at least 25-30 min after establishing the gigaohm seal (Fig. 8B). Pipette application of U0126 also prevented tLTP induction $(1.20 \pm 0.13, p=$ 

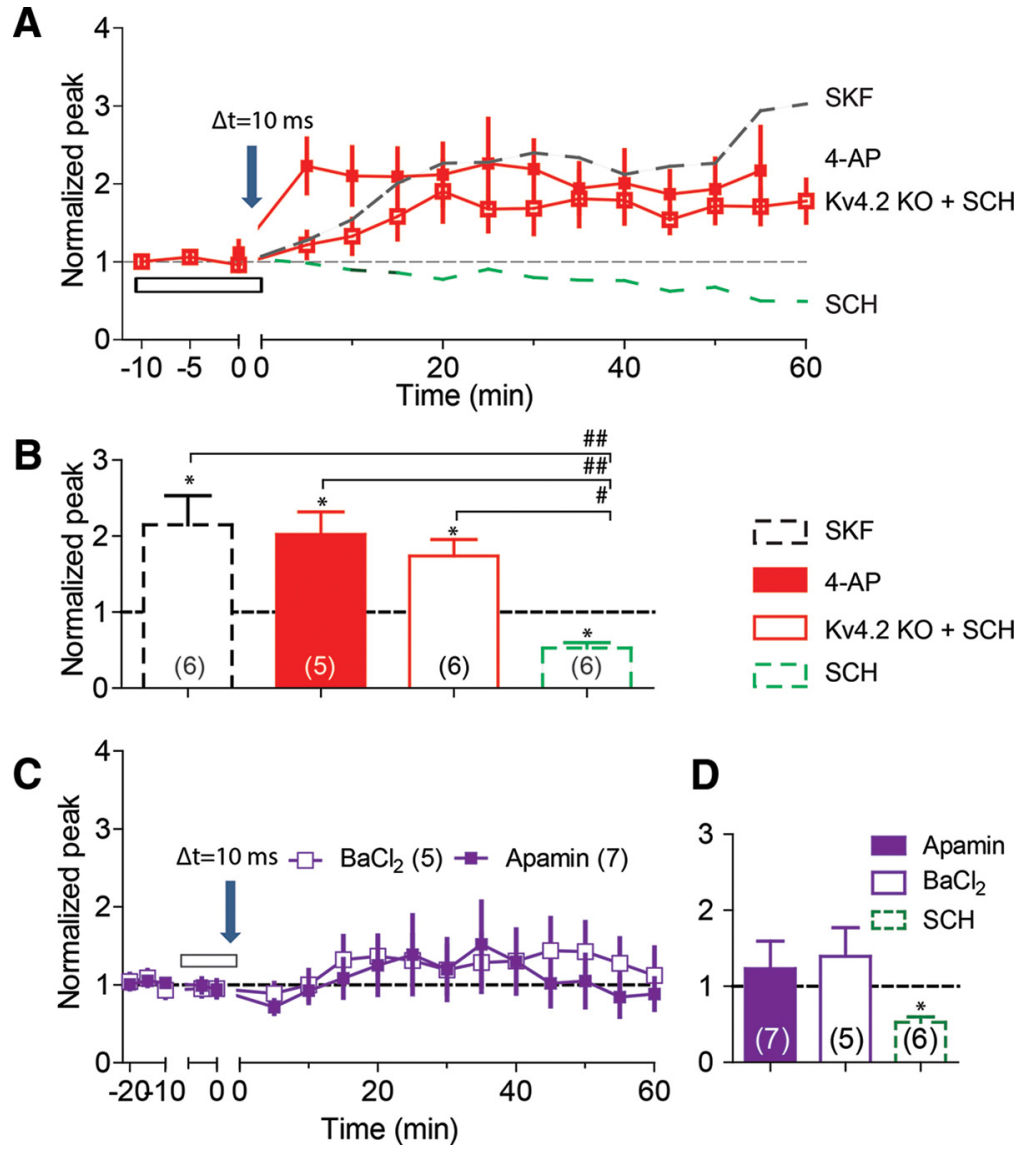

Figure 7. Effects of inactivation of $I_{A}$ and non- $I_{A}$ potassium channels on tLTP induction. $A$, The 10 ms protocol induces tLTP in slices from Kv4.2 KO mice even in the presence of SCH (red open box), but it induces LTD in slices from wild-type control mice (green dashed line taken from Fig. $2 \mathrm{C}$ ) in the presence of $\mathrm{SCH}$. The same protocol induces tLTP in slices from wild-type animals in the presence of $I_{A}$ inhibitor, $1 \mathrm{~mm}$ 4-AP (red filled box). For comparison, the $10 \mathrm{~ms}$ protocol in the presence of SKF induces comparable tLTP in slices from wild-type control mice (black dashed line taken from Fig. $3 A$ ). $\boldsymbol{B}$, Summary bar diagrams illustrating the effects of SKF, 4-AP, Kv4.2 KO, and SCH on tLTP induction by the 10 ms protocol. $C$, Neither SK inhibition (with $100 \mathrm{~nm}$ apamin, purple filled box) nor Kir inhibition (with $100 \mu \mathrm{M} \mathrm{BaCl}$, purple open box) significantly supports tLTP induction by the $10 \mathrm{~ms}$ protocol. The downward arrow indicates the application of the $10 \mathrm{~ms}$ protocol, and the open bars indicate the drug application. $\boldsymbol{D}$, Summary bar diagrams illustrating the effects of apamin, $\mathrm{BaCl}_{2}$, and SCH on tLTP induction. ${ }^{*} p<0.05$ compared with the baseline, and $\# p<0.01$, \#\#p $<0.005$ comparison between the indicated two groups.

0.19 vs baseline, $n=5$; Fig. $8 B, C$, purple circles). This result suggests that postsynaptic inhibition of the MAPK pathway within only the postsynaptic granule cell of interest is enough to suppress the STDP $(\Delta t=10 \mathrm{~ms})$ induction of synaptic plasticity.

We also examined the effects of U0126 on tLTP induction by the $30 \mathrm{~ms}$ protocol and found that bath application of U0126 (20 $\mu \mathrm{M})$ also successfully prevented the $30 \mathrm{~ms}$ protocol from inducing $\operatorname{tLTP}(1.20 \pm 0.13, p=0.19$ vs baseline, $n=7$; data not shown). Our data suggest that the activity of MAPK pathway has a critical role in determining tLTP expression that was modified by the DAergic system in dentate granule cells.

\section{NMDA dependence of tLTP induction}

NMDA receptor-dependent tLTP induction has been shown in cultured hippocampal neurons (J.C. Zhang et al., 2009), in CA1 pyramidal neurons in hippocampal slices (Edelmann and Lessmann, 2011), and at lateral perforant pathway synapses in the dentate gyrus (Lin et al., 2006). We observed that the STDP protocols with $\Delta t=10 \mathrm{~ms}$ (Fig. $9 A, B$ ) and $30 \mathrm{~ms}$ (Fig. 9C,D) failed to induce tLTP, respectively, when $100 \mu \mathrm{M}$ APV (NMDA receptor inhibitor) plus $30 \mu \mathrm{M}$ SKF was included in the perfusion solution. The overall findings indicate that NMDA receptors possibly control the direction of the synaptic plasticity change (Lüscher and Malenka, 2012) at medial perforant path to dentate granule cell synapses. For example, strong tLTP was induced by the $10 \mathrm{~ms}$ protocol when either $I_{A}$ was indirectly suppressed by D1-type receptor activation (Fig. 3) or $I_{A}$ was directly blocked by 4-AP (Fig. $7 A$ ). The underlying mechanism could possibly involve stronger NMDA receptor activation that resulted from boosted backpropagating action potentials caused by the $I_{A}$ inactivation. When D1 receptors were inactivated by $\mathrm{SCH}$, however, the $10 \mathrm{~ms}$ protocol only could result in modest depolarization and weaker activation of NMDA receptors, which resulted in LTD in the dentate gyrus (Figs. 2, 5; Lüscher and Malenka, 2012). Based on these results, we hypothesize that the induction of both LTP and LTD was NMDA receptor dependent (Lüscher and Malenka, 2012), and no significant changes in synaptic strength (Fig. 9) were observed once NMDA receptors were blocked by APV.

\section{Discussion}

The induction of tLTP depends on the order and timing of relatively low-frequency paired stimulation comprising presynaptic stimuli and postsynaptic action potential firing (Watanabe et al., 2002; J.C. Zhang et al., 2009; Edelmann and Lessmann, 2011; Markram et al., 2011). We found that the activation of D1-type DA receptors facilitated tLTP induction in dentate granule cells during STDP protocols with $\Delta t$ ranging at least $\pm 30 \mathrm{~ms}$. Using DA receptor KO mice, we showed that both D1 and D5 receptor subtypes were needed to produce tLTP using the $10 \mathrm{~ms}$ STDP protocol. Our results suggest that the inactivation of $I_{A}$ potassium current could serve as a downstream mechanism initiated by the activation of D1-type receptors.

\section{Spike timing-dependent plasticity varies with D1- type activity}

The direction and the extent of synaptic change are determined by the order and the relative timing of the presynaptic stimulation and postsynaptic action potential firing. In general, tLTP is induced when presynaptic stimuli precede postsynaptic action potential firing by $5-35 \mathrm{~ms}$, while tLTD is induced when the postsynaptic activity significantly precedes presynaptic stimulation (Bi and Poo, 1998; Abbott and Nelson, 2000; Feldman, 2000; Watanabe et al., 2002; Pawlak and Kerr, 2008; J.C. Zhang et al., 2009; Froemke et al., 2010; Edelmann and Lessmann, 2011). There is, however, significant variability in the plasticity induction rules when performed in various neuronal types and structures (Shulz and Jacob, 2010). For example, tLTD was induced 
with various STDP protocols (with $\Delta t=$ 10 to $30 \mathrm{~ms}$ ) applied to layer $2 / 3$ pyramidal cells of the medial prefrontal cortex (Zaitsev and Anwyl, 2012), applied to striatal neuronal nitric oxide synthase interneurons (Fino et al., 2009), and applied to spiny stellate neurons in layer 4 of somatosensory cortex (Egger et al., 1999). Interestingly, STDP protocols with longer $\Delta t$ (30 to $65 \mathrm{~ms})$ produced tLTP in striatal neuronal nitric oxide synthase interneurons (Fino et al., 2009) and in hippocampal CA1 pyramidal neurons (Watanabe et al., 2002).

Under our experimental conditions, after inhibiting D1-type receptors, the STDP protocols (with $\Delta t=-10,10 \mathrm{~ms}$ ) induced LTD (Fig. 5, blue data). The other timing protocols produced partially asymmetrical effects, and tLTP was only induced by the $30 \mathrm{~ms}$ protocol with D1-type receptors inhibited. Activation of D1-type receptors dramatically changed the direction of the synaptic strength change induced by the STDP protocols with relatively short $\Delta t$. For example, the $-30,30,-10$, and $10 \mathrm{~ms}$ protocols consistently induced tLTP when D1-type receptors were activated. In particular, D1-type receptor activation reversed tLTD to tLTP for the $\Delta t=-10,10 \mathrm{~ms}$ protocols (Fig. 5, red data). These observations indicate that in the presence of strong D1-type receptor activity, the "timing window" for the induction of tLTP is more widely open in dentate gyrus granule cells.

\section{Roles of dopamine signaling in tLTP induction}

Several lines of evidence from the present study demonstrate that D1-type receptor activation makes the $\mathrm{mPP}-$ granule cell connection more prone to tLTP induction. First, we found that the $10 \mathrm{~ms}$ STDP protocol (without bathapplied SKF or SCH) produced a large variation in the gain of synaptic strength, ranging from strong LTP to strong LTD (Fig. 2B, bottom). However, the same protocol after inhibition of D1-type receptors produced only LTD with little variability (Fig. $2 C$, bottom). The results suggest that the applied electrical stimulation in dentate gyrus slices induces variable endogenous DA release (Ihalainen et al., 1999). The extent of the stimulated DA release then influences the STDP induction with the $10 \mathrm{~ms}$ protocol. Second, direct activation of D1-type receptors with SKF increased tLTP induction by the STDP protocols with $\Delta t=-30$, -10 , and $10 \mathrm{~ms}$. Furthermore, with D1-type receptor activation, tLTD induction was reversed to tLTP during the -10 and 10 ms protocols. The DAergic facilitation of tLTP induction observed here is consistent with results from cultured hip-

C application from Figure $2 C$.
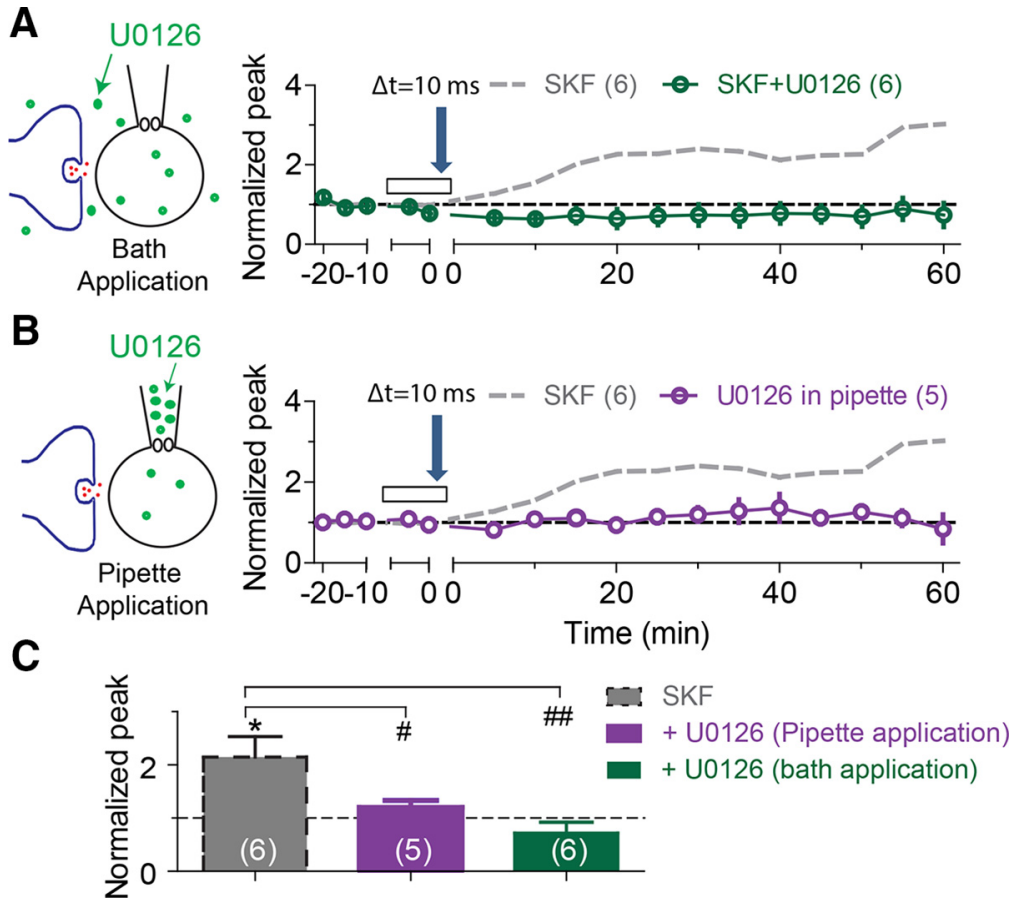

Figure 8. Selective MEK inhibitor, U0126, eliminates the enhancement effect of $30 \mu \mathrm{m}$ SKF on tLTP induction by the $10 \mathrm{~ms}$ protocol. $\boldsymbol{A}, \boldsymbol{B}$, Bath application $(\boldsymbol{A})$ or pipette application $(\boldsymbol{B})$ of $20 \mu \mathrm{m}$ U0126 prevents tLTP induction in the presence of $30 \mu \mathrm{m} \mathrm{SKF}$ pipette-applied U0126 on tLTP induction in the presence of SKF. ${ }^{*} p<0.05$ compared with the baseline. Dashed gray bar is for SKF
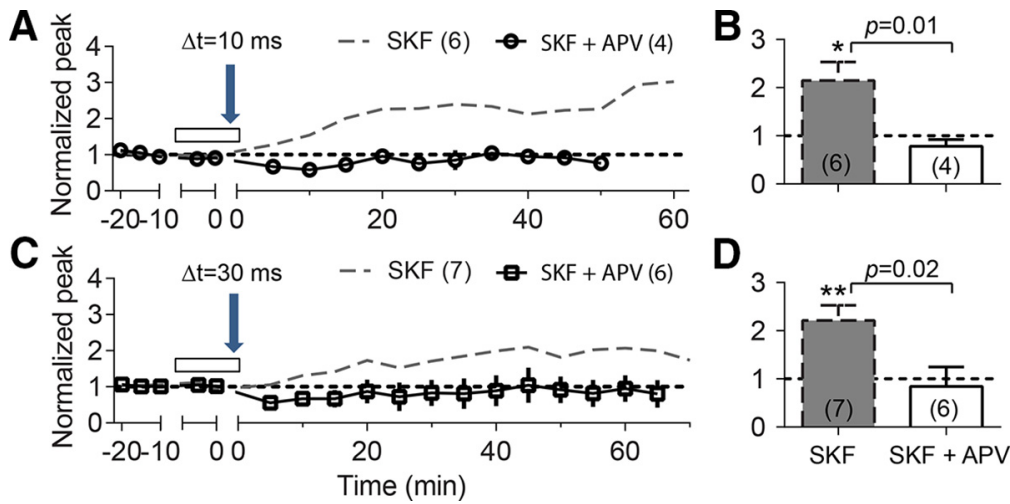

Figure 9. The STDP protocols induced tLTP that is NMDA receptor dependent. A, C, APV (100 $\mu \mathrm{m})$ prevents tLTP induction by the $10 \mathrm{~ms}(\boldsymbol{A})$ and the $30 \mathrm{~ms}(\boldsymbol{C})$ protocols in the presence of $30 \mu \mathrm{m}$ SKF. Dashed gray lines depict the enhancement effect of $30 \mu \mathrm{m}$ SKF (from Figs. $3 A$ and $4 A$, respectively). $\boldsymbol{B}, \boldsymbol{D}$, summary bar diagrams showing the effects of SKF and SKF + APV on tLTP induction by the $10 \mathrm{~ms}(\boldsymbol{A})$ and the $30 \mathrm{~ms}(\boldsymbol{C})$ protocols. ${ }^{*} p<0.05,{ }^{* *} p<0.01$ compared with the baseline and $p=0.01$ and $p=0.02$ comparison between the indicated two groups.

pocampal neurons (J.C. Zhang et al., 2009), from CA1 pyramidal neurons in rat hippocampal slices (Edelmann and Lessmann, 2011), and from granule cells in rat and human hippocampus (Hamilton et al., 2010). Third, when D1 or D5 receptors are not present (using knock-out mice), tLTP induction was impaired during the $10 \mathrm{~ms}$ protocol even with D1type receptors activated (Fig. 6). Similar results were found in the hippocampal CA1 area of D1 KO mice (Granado et al., 2008). Our study shows that both D1 and D5 receptor subtypes participate in lowering the tLTP induction threshold, which indicates the potential functional importance of the high D1 and D5 receptor mRNA in the dentate gyrus (Mu et al., 2011). 


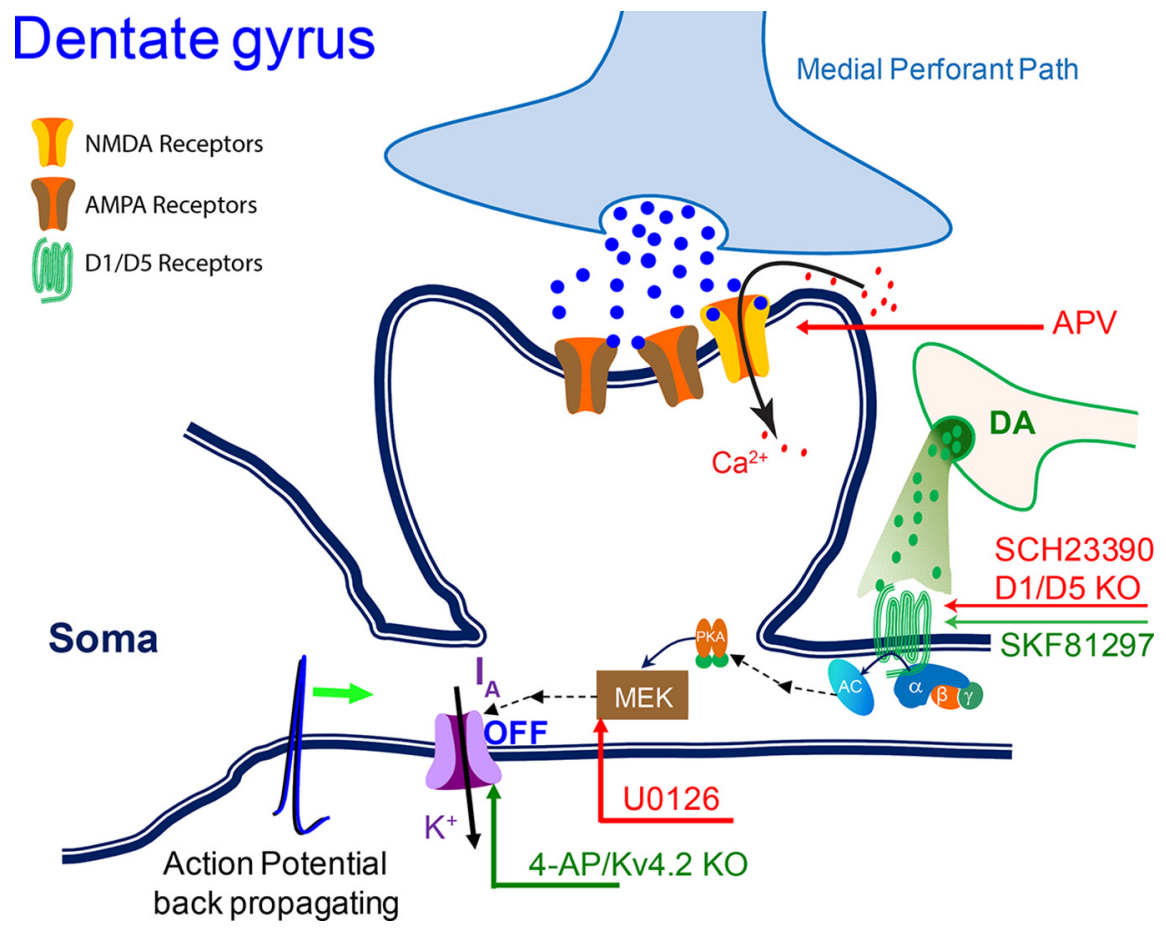

Figure 10. Didactic diagram illustrating a hypothetical mechanism underlying dopaminergic modulation of tLTP induction in dentate granule cells. A glutamate and DA input onto a granule cell synapse is shown. Experimental manipulations that decrease (red arrows) or boost (green arrows) tLTP induction at the locations indicated are shown with abbreviations used in the text. D1-type receptor activity initiates a multistep pathway via MEK to diminish $I_{A}$, which is mediated by the Kv4.2 potassium channel.

\section{Mechanisms of the DAergic modulation of tLTP induction}

With the $\Delta t=30 \mathrm{~ms}$ STDP protocol, tLTP is produced, and the amplitude of the tLTP is not highly responsive to D1-type activity (Fig. 4A). Similarly, the STDP protocol with $\Delta t=35 \mathrm{~ms}$ induced tLTP in hippocampal CA1 pyramidal neurons (Watanabe et al., 2002). That earlier study attributed the mechanism of the tLTP induction to an increased amplitude of backpropagating action potentials because of inactivation of the A-type potassium current $\left(I_{A}\right)$. In that way, the postsynaptic neuron became more excitable, and the STDP stimulation became more efficacious.

We examined the hypothesis that similar factors were at work over the wide STDP time range we examined in dentate granule cells. Figure 10 summarizes our hypothesis and findings. U0126 inhibits MEK (a tyrosine/threonine kinase) along the pathway to turn off $I_{A}$. With the $\Delta t=30 \mathrm{~ms}$ STDP protocol U0126 inhibits tLTP induction, but with this protocol D1-type activity has little effect. These results are consistent with the $\Delta t=30 \mathrm{~ms}$ STDP protocol boosting backpropagating action potentials without requiring D1-type receptor activity. However, if the backpropagating action potentials are diminished (by U0126) because a high density of $I_{A}$ decreases the input impedance, decreases the space constant, and repolarizes the neuron, then tLTP induction is prevented with the $\Delta t=30 \mathrm{~ms}$ protocol just as it is prevented at the $\Delta t=10 \mathrm{~ms}$ protocol by U0126. The data are consistent with activation of D1-type receptors acting via MEK (Yuan et al., 2002) to inactive the $I_{A}$ channels (Johnston et al., 1999; Watanabe et al., 2002; Yuan et al., 2002; Fig. 10). When we inhibited the $I_{A}$ channels directly with 4 -AP or used Kv4.2 KO mice (Fig. 7), this boosted tLTP induction by the $10 \mathrm{~ms}$ protocol comparable to that seen with D1-type receptor activation (Fig. $7 A, B$ ). The $10 \mathrm{~ms}$ protocol consistently induced tLTP in granule cells of Kv4.2 KO mice even while D1type receptors were inhibited by $\mathrm{SCH}$ (Fig. $7 A, B$ ). However, only tLTD was generated by the same protocol in slices from wild-type mice under the same experimental conditions (Fig. 2C). In summary, we have usedKv4.2 KO mice and several specific antagonists and agonists that act through different components of the MEK-MAPK signaling cascade to demonstrate that the activation of D1 and D5 receptors likely diminishes $I_{A}$ to boost tLTP induction.

\section{Physiological significance of DA modulation of tLTP induction}

In the hippocampus, neuronal activity propagating through the dentate gyrus influences the function of the entire hippocampus, including synaptic potentiation and memory (Cho et al., 2007; Saab et al., 2009; Stepan et al., 2012). In particular, the MPP carries place and spatial information, including, for example, the locations of food or drug resources (Hargreaves et al., 2005; Van Cauter et al., 2013). When D1-type receptors were not active, only the $30 \mathrm{~ms}$ STDP protocol induced tLTP in dentate granule cells. This situation demands a tight causal relationship between incoming afferent activities along the $\mathrm{mPP}$ and relatively precisely timed postsynaptic responses. This timing relationship suggests that afferent information (e.g., environmental information) contributes to the postsynaptic response necessary for synaptic plasticity and potentially memory. However, strong activation of D1-type receptors greatly expanded the tLTP induction timing window (Fig. 5). This result suggests that when the DA signal is large synaptic plasticity is more likely, and the demand for a causal relationship between afferent inputs driving the postsynaptic response is relaxed. Large DA signals are transmitted when unexpected, highly rewarding events are encountered in the environment (Schultz et al., 1997; Bayer and Glimcher, 2005). Therefore, to extrapolate the results simplistically, when an unexpected, highly rewarding event induces a large DA signal, then the timing for LTP induction is relaxed such that any activity occurring within the postsynaptic neurons is more susceptible for potentiation. That is, no matter how the postsynaptic activity was generated, within a given timing window, afferent activity is capable of inducing tLTP. As an important part of the brain's reward circuit (Ricoy and Martinez, 2009), the hippocampus also has a critical role in the development of drug addiction (Biala et al., 2005). Therefore, the excessive DA signaling induced by addictive drugs will dramatically facilitate drug-associated place and spatial memories. On the other hand, decreases in levels of endogenous DA resulting from neurodegenerative diseases, such as Parkinson's disease, may cause impairment in learning and memory (Ardayfio et al., 2008; Raskin et al., 2011; Foster et al., 2013; Solari et al., 2013). 


\section{References}

Abbott LF, Nelson SB (2000) Synaptic plasticity: taming the beast. Nat Neurosci [3 Suppl]:1178-1183. CrossRef Medline

Ardayfio P, Moon J, Leung KK, Youn-Hwang D, Kim KS (2008) Impaired learning and memory in Pitx3 deficient aphakia mice: a genetic model for striatum-dependent cognitive symptoms in Parkinson's disease. Neurobiol Dis 31:406-412. CrossRef Medline

Astori S, Pawlak V, Köhr G (2010) Spike-timing-dependent plasticity in hippocampal CA3 neurons. J Physiol 588:4475-4488. CrossRef Medline

Bayer HM, Glimcher PW (2005) Midbrain dopamine neurons encode a quantitative reward prediction error signal. Neuron 47:129-141. CrossRef Medline

Benesova J, Rusnakova V, Honsa P, Pivonkova H, Dzamba D, Kubista M, Anderova M (2012) Distinct expression/function of potassium and chloride channels contributes to the diverse volume regulation in cortical astrocytes of GFAP/EGFP mice. PLoS One 7:e29725. CrossRef Medline

Bi GQ, Poo MM (1998) Synaptic modifications in cultured hippocampal neurons: dependence on spike timing, synaptic strength, and postsynaptic cell type. J Neurosci 18:10464-10472. Medline

Biala G, Betancur C, Mansuy IM, Giros B (2005) The reinforcing effects of chronic D-amphetamine and morphine are impaired in a line of memory-deficient mice overexpressing calcineurin. Eur J Neurosci 21: 3089-3096. CrossRef Medline

Brenner R, Chen QH, Vilaythong A, Toney GM, Noebels JL, Aldrich RW (2005) BK channel beta4 subunit reduces dentate gyrus excitability and protects against temporal lobe seizures. Nat Neurosci 8:1752-1759. CrossRef Medline

Chen X, Yuan LL, Zhao C, Birnbaum SG, Frick A, Jung WE, Schwarz TL, Sweatt JD, Johnston D (2006) Deletion of Kv4.2 gene eliminates dendritic A-type $\mathrm{K}+$ current and enhances induction of long-term potentiation in hippocampal CA1 pyramidal neurons. J Neurosci 26:12143-12151. CrossRef Medline

Cho MH, Cao X, Wang D, Tsien JZ (2007) Dentate gyrus-specific manipulation of beta-Ca2+/calmodulin-dependent kinase II disrupts memory consolidation. Proc Natl Acad Sci U S A 104:16317-16322. CrossRef Medline

Dan Y, Poo MM (2006) Spike timing-dependent plasticity: from synapse to perception. Physiol Rev 86:1033-1048. CrossRef Medline

da Silva WC, Köhler CC, Radiske A, Cammarota M (2012) D1/D5 dopamine receptors modulate spatial memory formation. Neurobiol Learn Mem 97:271-275. CrossRef Medline

Duan KZ, Xu Q, Zhang XM, Zhao ZQ, Mei YA, Zhang YQ (2012) Targeting A-type $\mathrm{K}(+)$ channels in primary sensory neurons for bone cancer pain in a rat model. Pain 153:562-574. CrossRef Medline

Edelmann E, Lessmann V (2011) Dopamine modulates spike timingdependent plasticity and action potential properties in CA1 pyramidal neurons of acute rat hippocampal slices. Front Synaptic Neurosci 3:6. CrossRef Medline

Edelmann E, Lessmann V (2013) Dopamine regulates intrinsic excitability thereby gating successful induction of spike timing-dependent plasticity in CA1 of the hippocampus. Front Neurosci 7:25. CrossRef Medline

Egger V, Feldmeyer D, Sakmann B (1999) Coincidence detection and changes of synaptic efficacy in spiny stellate neurons in rat barrel cortex. Nat Neurosci 2:1098-1105. CrossRef Medline

Feldman DE (2000) Timing-based LTP and LTD at vertical inputs to layer II/III pyramidal cells in rat barrel cortex. Neuron 27:45-56. CrossRef Medline

Fino E, Paille V, Deniau JM, Venance L (2009) Asymmetric spike-timing dependent plasticity of striatal nitric oxide-synthase interneurons. Neuroscience 160:744-754. CrossRef Medline

Foster ER, Rose NS, McDaniel MA, Rendell PG (2013) Prospective memory in Parkinson disease during a virtual week: effects of both prospective and retrospective demands. Neuropsychology 27:170-181. CrossRef Medline

Froemke RC, Debanne D, Bi GQ (2010) Temporal modulation of spiketiming-dependent plasticity. Front Synaptic Neurosci 2:19. CrossRef Medline

Gallagher SM, Daly CA, Bear MF, Huber KM (2004) Extracellular signalregulated protein kinase activation is required for metabotropic glutamate receptor-dependent long-term depression in hippocampal area CA1. J Neurosci 24:4859-4864. CrossRef Medline

Gasbarri A, Packard MG, Campana E, Pacitti C (1994a) Anterograde and retrograde tracing of projections from the ventral tegmental area to the hippocampal formation in the rat. Brain Res Bull 33:445-452. CrossRef Medline

Gasbarri A, Verney C, Innocenzi R, Campana E, Pacitti C (1994b) Mesolimbic dopaminergic neurons innervating the hippocampal formation in the rat: a combined retrograde tracing and immunohistochemical study. Brain Res 668:71-79. CrossRef Medline

Gasbarri A, Packard MG, Sulli A, Pacitti C, Innocenzi R, Perciavalle V (1996) The projections of the retrorubral field A8 to the hippocampal formation in the rat. Exp Brain Res 112:244-252. CrossRef Medline

Granado N, Ortiz O, Suárez LM, Martin ED, Ceña V, Solís JM, Moratalla R (2008) D1 but not D5 dopamine receptors are critical for LTP, spatial learning, and LTP-Induced arc and zif268 expression in the hippocampus. Cereb Cortex 18:1-12. CrossRef Medline

Gu C, Jan YN, Jan LY (2003) A conserved domain in axonal targeting of Kv1 (Shaker) voltage-gated potassium channels. Science 301:646-649. CrossRef Medline

Hamilton TJ, Wheatley BM, Sinclair DB, Bachmann M, Larkum ME, Colmers WF (2010) Dopamine modulates synaptic plasticity in dendrites of rat and human dentate granule cells. Proc Natl Acad Sci U S A 107:1818518190. CrossRef Medline

Hansen N, Manahan-Vaughan D (2014) Dopamine D1/D5 receptors mediate informational saliency that promotes persistent hippocampal longterm plasticity. Cereb Cortex 24:845-858. CrossRef Medline

Hargreaves EL, Rao G, Lee I, Knierim JJ (2005) Major dissociation between medial and lateral entorhinal input to dorsal hippocampus. Science 308: 1792-1794. CrossRef Medline

Hsu D (2007) The dentate gyrus as a filter or gate: a look back and a look ahead. Prog Brain Res 163:601-613. CrossRef Medline

Ihalainen JA, Riekkinen P Jr, Feenstra MG (1999) Comparison of dopamine and noradrenaline release in mouse prefrontal cortex, striatum and hippocampus using microdialysis. Neurosci Lett 277:71-74. CrossRef Medline

Iñiguez SD, Charntikov S, Baella SA, Herbert MS, Bolaños-Guzmán CA, Crawford CA (2012) Post-training cocaine exposure facilitates spatial memory consolidation in C57BL/6 mice. Hippocampus 22:802-813. CrossRef Medline

Johnston D, Hoffman DA, Colbert CM, Magee JC (1999) Regulation of back-propagating action potentials in hippocampal neurons. Curr Opin Neurobiol 9:288-292. CrossRef Medline

Kelleher RJ 3rd, Govindarajan A, Jung HY, Kang H, Tonegawa S (2004) Translational control by MAPK signaling in long-term synaptic plasticity and memory. Cell 116:467-479. CrossRef Medline

Kheirbek MA, Drew LJ, Burghardt NS, Costantini DO, Tannenholz L, Ahmari SE, Zeng H, Fenton AA, Hen R (2013) Differential control of learning and anxiety along the dorsoventral axis of the dentate gyrus. Neuron 77:955-968. CrossRef Medline

Kodangattil JN, Dacher M, Authement ME, Nugent FS (2013) Spike timingdependent plasticity at GABAergic synapses in the ventral tegmental area. J Physiol 591:4699-4710. CrossRef Medline

Lin YW, Min MY, Chiu TH, Yang HW (2003) Enhancement of associative long-term potentiation by activation of beta-adrenergic receptors at CA1 synapses in rat hippocampal slices. J Neurosci 23:4173-4181. Medline

Lin YW, Yang HW, Wang HJ, Gong CL, Chiu TH, Min MY (2006) Spiketiming-dependent plasticity at resting and conditioned lateral perforant path synapses on granule cells in the dentate gyrus: different roles of $\mathrm{N}$-methyl-D-aspartate and group I metabotropic glutamate receptors. Eur J Neurosci 23:2362-2374. CrossRef Medline

Lisman JE, Grace AA (2005) The hippocampal-VTA loop: controlling the entry of information into long-term memory. Neuron 46:703-713. CrossRef Medline

Liu YB, Lio PA, Pasternak JF, Trommer BL (1996) Developmental changes in membrane properties and postsynaptic currents of granule cells in rat dentate gyrus. J Neurophysiol 76:1074-1088. Medline

Lüscher C, Malenka RC (2012) NMDA receptor-dependent long-term potentiation and long-term depression (LTP/LTD). Cold Spring Harb Perspect Biol 4:a005710. CrossRef Medline

Luu P, Malenka RC (2008) Spike timing-dependent long-term potentiation in ventral tegmental area dopamine cells requires PKC. J Neurophysiol 100:533-538. CrossRef Medline

Markram H, Gerstner W, Sjöström PJ (2011) A history of spike-timingdependent plasticity. Front Synaptic Neurosci 3:4. CrossRef Medline

Mu Y, Zhao C, Gage FH (2011) Dopaminergic modulation of cortical in- 
puts during maturation of adult-born dentate granule cells. J Neurosci 31:4113-4123. CrossRef Medline

Patel LS, Wenzel HJ, Schwartzkroin PA (2004) Physiological and morphological characterization of dentate granule cells in the p35 knock-out mouse hippocampus: evidence for an epileptic circuit. J Neurosci 24: 9005-9014. CrossRef Medline

Pawlak V, Kerr JN (2008) Dopamine receptor activation is required for corticostriatal spike-timing-dependent plasticity. J Neurosci 28:2435-2446. CrossRef Medline

Raskin SA, Woods SP, Poquette AJ, McTaggart AB, Sethna J, Williams RC, Tröster AI (2011) A differential deficit in time- versus event-based prospective memory in Parkinson's disease. Neuropsychology 25:201-209. CrossRef Medline

Ricoy UM, Martinez JL Jr (2009) Local hippocampal methamphetamineinduced reinforcement. Front Behav Neurosci 3:47. CrossRef Medline

Saab BJ, Georgiou J, Nath A, Lee FJ, Wang M, Michalon A, Liu F, Mansuy IM, Roder JC (2009) NCS-1 in the dentate gyrus promotes exploration, synaptic plasticity, and rapid acquisition of spatial memory. Neuron 63:643656. CrossRef Medline

Scharfman HE (1992) Differentiation of rat dentate neurons by morphology and electrophysiology in hippocampal slices: granule cells, spiny hilar cells and aspiny 'fast-spiking' cells. Epilepsy Res [Suppl 7]:93-109. Medline

Schultz W (1997) Dopamine neurons and their role in reward mechanisms. Curr Opin Neurobiol 7:191-197. CrossRef Medline

Schultz W, Dayan P, Montague PR (1997) A neural substrate of prediction and reward. Science 275:1593-1599. CrossRef Medline

Seol GH, Ziburkus J, Huang S, Song L, Kim IT, Takamiya K, Huganir RL, Lee HK, Kirkwood A (2007) Neuromodulators control the polarity of spiketiming-dependent synaptic plasticity. Neuron 55:919-929. CrossRef Medline

Sheng M, Tsaur ML, Jan YN, Jan LY (1992) Subcellular segregation of two A-type K+ channel proteins in rat central neurons. Neuron 9:271-284. CrossRef Medline

Shulz DE, Jacob V (2010) Spike-timing-dependent plasticity in the intact brain: counteracting spurious spike coincidences. Front Synaptic Neurosci 2:137. CrossRef Medline

Smith CC, Greene RW (2012) CNS dopamine transmission mediated by noradrenergic innervation. J Neurosci 32:6072-6080. CrossRef Medline

Solari N, Bonito-Oliva A, Fisone G, Brambilla R (2013) Understanding cognitive deficits in Parkinson's disease: lessons from preclinical animal models. Learn Mem 20:592-600. CrossRef Medline

Stepan J, Dine J, Fenzl T, Polta SA, von Wolff G, Wotjak CT, Eder M (2012) Entorhinal theta-frequency input to the dentate gyrus trisynaptically evokes hippocampal CA1 LTP. Front Neural Circuits 6:64. CrossRef Medline

Tang J, Dani JA (2009) Dopamine enables in vivo synaptic plasticity associated with the addictive drug nicotine. Neuron 63:673-682. CrossRef Medline

Van Cauter T, Camon J, Alvernhe A, Elduayen C, Sargolini F, Save E (2013)
Distinct roles of medial and lateral entorhinal cortex in spatial cognition. Cereb Cortex 23:451-459. CrossRef Medline

Velázquez-Marrero C, Wynne P, Bernardo A, Palacio S, Martin G, Treistman SN (2011) The relationship between duration of initial alcohol exposure and persistence of molecular tolerance is markedly nonlinear. J Neurosci 31:2436-2446. CrossRef Medline

Watanabe S, Hoffman DA, Migliore M, Johnston D (2002) Dendritic K+ channels contribute to spike-timing dependent long-term potentiation in hippocampal pyramidal neurons. Proc Natl Acad Sci U S A 99:83668371. CrossRef Medline

Wu SP, Lu KT, Chang WC, Gean PW (1999) Involvement of mitogenactivated protein kinase in hippocampal long-term potentiation. J Biomed Sci 6:409-417. CrossRef Medline

Yang F, Feng L, Zheng F, Johnson SW, Du J, Shen L, Wu CP, Lu B (2001) GDNF acutely modulates excitability and A-type $\mathrm{K}(+)$ channels in midbrain dopaminergic neurons. Nat Neurosci 4:1071-1078. CrossRef Medline

Yang K, Hu J, Lucero L, Liu Q, Zheng C, Zhen X, Jin G, Lukas RJ, Wu J (2009) Distinctive nicotinic acetylcholine receptor functional phenotypes of rat ventral tegmental area dopaminergic neurons. J Physiol 587:345-361. CrossRef Medline

Yang K, Buhlman L, Khan GM, Nichols RA, Jin G, McIntosh JM, Whiteaker P, Lukas RJ, Wu J (2011) Functional nicotinic acetylcholine receptors containing \{alpha\} 6 subunits are on GABAergic neuronal boutons adherent to ventral tegmental area dopamine neurons. J Neurosci 31:25372548. CrossRef Medline

Yang K, Zhang J, Wu J (2013) Nicotinic modulation of $\mathrm{GABA}_{\mathrm{A}}$ receptor function in single dopaminergic neurons freshly dissociated from rat substantia nigra pars compacta. Biochem Pharmacol S1:003. CrossRef

Young CC, Stegen M, Bernard R, Müller M, Bischofberger J, Veh RW, Haas CA, Wolfart J (2009) Upregulation of inward rectifier K+ (Kir2) channels in dentate gyrus granule cells in temporal lobe epilepsy. J Physiol 587:4213-4233. CrossRef Medline

Yuan LL, Adams JP, Swank M, Sweatt JD, Johnston D (2002) Protein kinase modulation of dendritic $\mathrm{K}+$ channels in hippocampus involves a mitogen-activated protein kinase pathway. J Neurosci 22:4860-4868. Medline

Yu SP, Farhangrazi ZS, Ying HS, Yeh CH, Choi DW (1998) Enhancement of outward potassium current may participate in beta-amyloid peptideinduced cortical neuronal death. Neurobiol Dis 5:81-88. CrossRef Medline

Zaitsev AV, Anwyl R (2012) Inhibition of the slow afterhyperpolarization restores the classical spike timing-dependent plasticity rule obeyed in layer 2/3 pyramidal cells of the prefrontal cortex. J Neurophysiol 107:205215. CrossRef Medline

Zhang JC, Lau PM, Bi GQ (2009) Gain in sensitivity and loss in temporal contrast of STDP by dopaminergic modulation at hippocampal synapses. Proc Natl Acad Sci U S A 106:13028-13033. CrossRef Medline

Zhang TA, Tang J, Pidoplichko VI, Dani JA (2010) Addictive nicotine alters local circuit inhibition during the induction of in vivo hippocampal synaptic potentiation. J Neurosci 30:6443-6453. CrossRef Medline 